\title{
THE IMPACT OF UNDER-VINE MANAGEMENT ON THE WEED SEEDBANK IN THE SOIL
}

\author{
Lenka Porčová ${ }^{1}$ Vladimír Smutný ${ }^{1}$ \\ ${ }^{1}$ Department of Agrosystems and Bioclimatology, Faculty of AgriSciences, Mendel University in Brno, \\ Zemědělská 1, 61300 Brno, Czech Republic
}

To cite this article: PORČOVÁ LENKA, SMUTNÝ VLADIMÍR. 2018. The Impact of Under-Vine Management on the Weed Seedbank in the Soil. Acta Universitatis Agriculturae et Silviculturae Mendelianae Brunensis, 66(5): 1165-1170.

To link to this article: https://doi.org/10.11118/actaun201866051165

\begin{abstract}
The evaluation of the weed seedbank in the soil was carried out in 2013 and 2014 in the Žabčice vineyard. Within the frame of maintenance management, three methods of under-vine management were proposed: untreated control, chemical and mechanical method of weed management. 23 plant species were identified in the soil samples from the place below the grapevine. The obtained data were evaluated by the analysis of variance (ANOVA). Seeds of the species Amaranthus sp., Chenopodium album, Stellaria media, and Portulaca oleracea were the most common in all variants. Soil samples from the variant of mechanical weed management were the richest from the perspective of species. This variant also contained the smallest number of seeds per $\mathrm{m}^{2}$ of soil.
\end{abstract}

Keywords: weed seedbank, weed control, vineyard, under-vine management, mechanical and chemical methods

\section{INTRODUCTION}

The study of weed seed-bank in the soil is important for understanding dynamic changes in the weed population and the prediction of future actual weed infestation. Authors Olano et al. (2012), Caballero et al. (2008), Miriti et al. (2007), Caballero et al. (2005) in their experiments concluded that the soil seed supply consists mainly of a large number of newly disseminated seeds. Our aim should be to reduce this seed supply in the soil gradually. Caetano et al. (2001) argues that weed seeds and fruits in the surface part of the soil profile determine the composition of the future actual weed infestation. Dvořák and Smutný (2011) state that increasing in the potential weed infestation would probably be followed by an increase in the actual weed infestation. Nevertheless, a high seed supply of a certain species may not, in certain cases, manifest in the immediate strong presence of this species in the vegetation as said Dvořák and
Krejčír (1973). By determining the potential weed infestation of soil, we can also evaluate the success of our weed management interventions. This work evaluates the effectiveness of the mechanical and chemical methods of weed management in the places below the grapevine by analyzing the soil seedbank.

\section{MATERIALS AND METHODS}

The experiment was carried out in the vineyard of the University Agriculture Farm of Mendel University in Žabčice. The village is located about $25 \mathrm{~km}$ south of Brno, in the Brno-Country District. The vineyards belong to the wine region of Moravia, to the northernmost part of the wine sub-region of Velké Pavlovice. Lands are of a flat nature, not threatened by water erosion, with an altitude of $185 \mathrm{~m}$ a. s. l. During the norm period of 1961-1990, the average annual temperature was $9.2^{\circ} \mathrm{C}$; 
the average annual rainfall was $480 \mathrm{~mm}$. The Lang's Rain Index value is approximately 52, which classifies the experimental site among the driest regions of the Czech Republic.

The vineyard, in which the experiment took place, was planted in 2007 and the wine grape variety Pinot Blanc is grown. Due to the precipitation conditions, grass-covered and cultivated inter-space between rows alternate in the vineyard. The experimental site is located on the GPS coordinates of 49.0031 North and 16.5845 West. The soil in the horizon A $(0-0.30 \mathrm{~m})$ was tested for the content of available nutrients by the Mehlich III method in 2013. The phosphorus content was high (131 mg/kg), the potassium content was high $(350 \mathrm{mg} / \mathrm{kg})$, the magnesium content was satisfactory (120 mg/kg), the calcium content was $513 \mathrm{mg} / \mathrm{kg}$, and the soil $\mathrm{pH}$ was 6.03. The analysis of soil granularity was as follows: the fraction lower than $0.001 \mathrm{~mm}$ (9.27\%), fraction $0.001-0.05 \mathrm{~mm}$ (13.97\%), fraction greater than $0.05 \mathrm{~mm}$ (76.76\%). Soil was classified as sandy loam. The amount of $\mathrm{Co}_{\mathrm{x}}$ in the soil was $1.3 \%$.

For the purposes of the experiment, three variants of under-vine management were proposed:

- Control variant - untreated; the control places below the vineyard were hoed by a hoe due to better absorption of spring precipitation. During the entire vegetation period, the occurrence of weed was not controlled. Just before harvesting the grapes, the weed was mowed with a brush-cutter, due to sufficient access to the grape zone.

- Chemically controlled variant - chemical weed control; hoe was used for the first spring treatment; weeds were further controlled by recommended doses of herbicides. The overview of used preparations and more details are stated in Tab I.

- Mechanically controlled variant - mechanical weed control; weed was exclusively controlled mechanically (by a hoe). Hoeing was carried out at the same time as chemical treatment.

The modified methodology by Dvořák and Krejčíř (1973), adjusted by Smutný and Křen (2002), was used for the evaluation of the weed seedbank in the soil samples. Soil samples were taken on $16^{\text {th }}$ October 2013 and $9^{\text {th }}$ October 2014 from 6 places below the grapevine (2 untreated places, 2 mechanically controlled places, 2 chemically controlled places). 5 compound samples were taken from each place. In total, 30 compound soil samples were taken. The soil was taken from the horizon
A. Each compound soil sample of a total weight of about $5 \mathrm{~kg}$ was taken to a marked plastic bag and subsequently dried at laboratory temperature on aluminum plates. After drying, $100 \mathrm{~g}$ samples were weighed in two repetitions. They were sieved by a vibratory sieve shaker ANALYSETTE 3. Two sieves were used for sieving. The top sieve had a mesh size of $0.5 \mathrm{~cm}$ and coarser fractions of a skeleton and an organic component (e.g. grape seeds, insect, crop residues, etc.) remained after processing through it. Weed seeds and fruit were captured by this sieve only exceptionally. Naturally, these seeds were added to a finer fraction. The bottom sieve had a mesh size of $0.025 \mathrm{~cm}$ and the finest fraction of a soil skeleton, a large amount of sand, weed seeds and fruit remained after processing through it. The extracted fraction was transferred by a wash bottle to a funnel with a folded filter paper without any residue, and after filtration, it was dried at room temperature. From the dried mixture, weed seeds and fruits were selected under the binocular magnifier using a tweezer, which were identified and counted using the program ImageJ; Schneider, Rasband and Eliceiri (2012). Latin names of weed species were used according to Marhold and Hindák (1998). The number of seeds per $1 \mathrm{~m}^{2}$ of soil was further calculated using the adjusted coefficient Ć calculated from the formula:

$\bar{C}=\frac{10000 \cdot h \cdot B D}{g}$,

where:

$\mathrm{h}=$ depth of sampling $(\mathrm{cm})$

$\mathrm{BD}=$ value of the bulk density $\left(\mathrm{g} \cdot \mathrm{cm}^{-3}\right)$

$\mathrm{g}=$ weight of an average sample (g).

Calculation of the value of the equilibrium volume weight of the soil (BD) was taken from the methodology of the Soil Science and Conservation Research Institute in Bratislava (VÚPOP, 2017). The obtained data were statistically evaluated by the analysis of variance (ANOVA).

\section{RESULTS}

24 plant species were found in the soil samples from the evaluated places below the grapevine. They are ordered alphabetically: Alnus glutinosa, Amaranthus sp., Cardaria draba, Carduus acanthoides,

I: Overview of herbicides applied in the places below the grapevine

\begin{tabular}{|c|c|c|}
\hline Date & Name of herbicide & Dose (l/ha) \\
\hline $21^{\text {st }}$ June, 2013 & Basta 15* & 2,0 \\
\hline $1^{\text {st }}$ April, 2014 & Roundup Rapid** & 1,33 \\
\hline $11^{\text {th }}$ June, 2014 & Basta $15^{*}$ & 1,9 \\
\hline $25^{\text {th }}$ July, 2014 & Basta $15^{*}$ & 1,9 \\
\hline
\end{tabular}

*: Active Ingredient: Glufosinate-ammonium

**: Active Ingredient: Glyphosate 
Digitaria sanguinalis, Echinochloa crus-galli, Erodium cicutarium, Galium verum, Holosteum umbellatum, Chenopodium album, Lamium amplexicaule, Lamium purpureum, Malva neglecta, Matricaria perforata, Plantago lanceolata, Poa annua, Polygonum aviculare, Portulaca oleracea, Ranunculus repens, Senecio vulgaris, Stellaria media, Taraxacum spp., Thlaspi arvense and Tripleurospermum perforatum. Seeds of annual plant species predominate, which make up $99.6 \%$ of the total seed volume in the soil.

It was identified seeds of 13 weed species in soil samples from the untreated variant. It was 14 weed species in the chemically controlled variant. The richest soil samples were from the mechanically controlled variant, containing seeds of 17 species of weeds. In all maintenance variants, the largest number of seeds (97.5\%) were the same types of weeds, specifically Amaranthus sp., Portulaca oleracea, Chenopodium album and Stellaria media. The occurrence of these species in the evaluated variants is shown on Fig. 1. The genus of Amaranthus and Chenopodium are generally classified as dangerous weed species. Both species are sturdy, and an exceptionally high seed production characterizes them. The species Portulaca oleracea and Stellaria media, on the other hand, are species of low growth but they also produce a large number of seeds. Both of these species grow mostly horizontally and are able to cover the free surface of the soil quickly.

With regard to the average amount of seeds per square meter of soil (Fig. 2), the most seeds were, of course, found in the soil sample from the untreated variant, on average 28,000 seeds per $1 \mathrm{~m}^{2}$ of soil. In this variant, the average number of seeds per $\mathrm{m}^{2}$ of soil was statistically higher than in the mechanically controlled variant (at the level of significance $\alpha=0.01$ ). In the chemically controlled variant, the soil contained on average 25,500 seeds per $1 \mathrm{~m}^{2}$ of soil. The least seeds were found in the mechanically controlled variant, on average 19,500 seeds per $\mathrm{m}^{2}$. The difference in the average number of seeds between the chemically and mechanically controlled variants was not statistically significant.

The results of the analysis of variance (Tab. II) confirmed that the factor of the year did not have a significant impact on the number of seeds in the soil. The factor of the variant of under-vine management had a highly statistically significant impact on the number of seeds in the soil (at the level of significance $\alpha=0.01$ ). Also, the interaction year*variant of maintenance (Fig. 3) did have a statistically significant impact on the number of seeds in the soil. The graph shows a year-on-year increase in the average number of seeds in the untreated variant. In 2014, the average number of seeds in the soil was higher by almost 15,000 seeds compared to 2013 . In the chemically controlled variant, the average number of seeds in 2013 was lower than in the untreated variant and continued to decline in 2014. In the mechanically controlled variant, the average number of seeds per $1 \mathrm{~m}^{2}$ was lower than in the chemically controlled and untreated variant in 2013 and decreased by almost 7,500 seeds in 2014 .

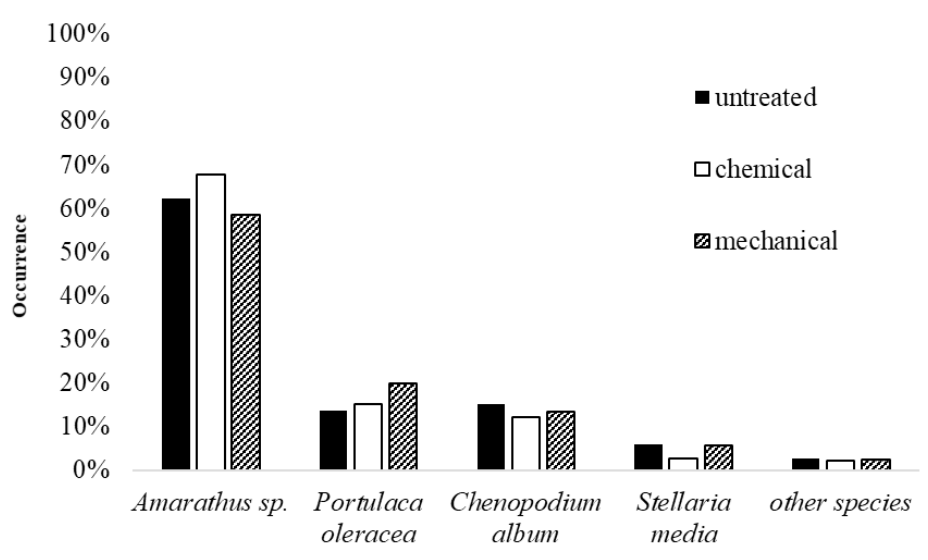

Weed species

1: Seed occurrence of the most frequent weed species

II: Effect of various factors on the number of seeds in the soil, analysis of variance

\begin{tabular}{lccccc}
\hline \multicolumn{1}{c}{ Source of variability } & Sum of squares & $\begin{array}{c}\text { Degrees of } \\
\text { freedom }\end{array}$ & Mean squares & F value & p value \\
\hline Year & 6341006 & 1 & 6341006 & 0,0731 & 0,7873 \\
Variant of maintenance & 1174152544 & 2 & 587076272 & 6,7750 & $0,0017^{* *}$ \\
Year*variant of maintenance & 1813737004 & 2 & 906868502 & 10,4655 & $0,0000^{* *}$ \\
Error & 8145365120 & 94 & 86652820 & & \\
\hline
\end{tabular}

** highly statistically significant impact $(\alpha=0,01)$ 


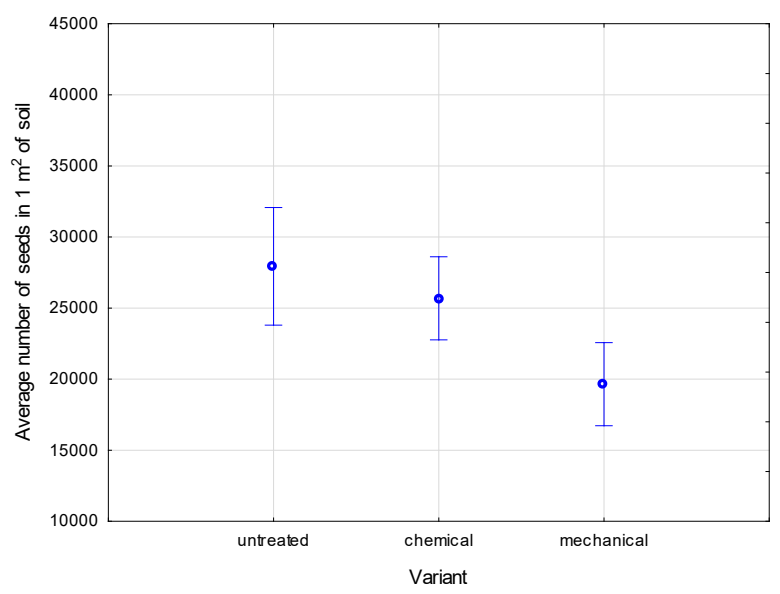

2: Average number of seeds in the soil on the evaluated variants

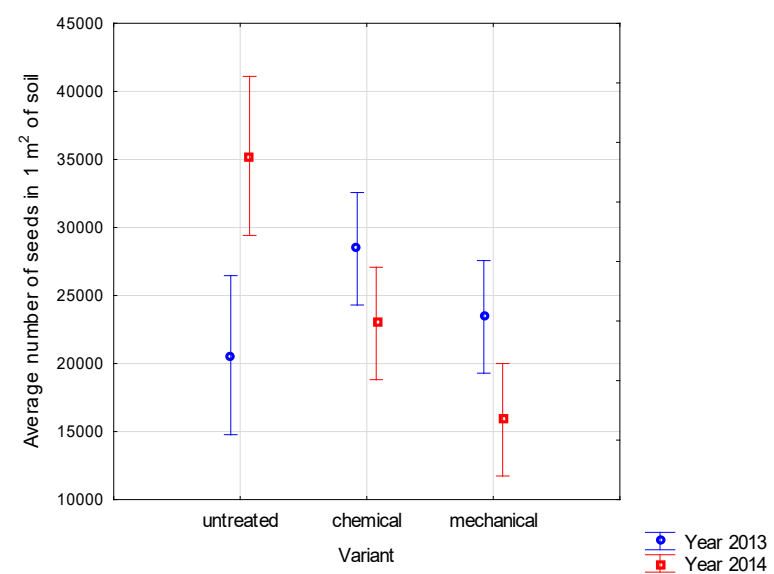

3: The impact of interaction year*variant of maintenance on number of seeds

\section{DISCUSSION}

In all maintenance variants, the soil samples contained mainly the seeds of the genus Amaranthus and species Portulaca oleracea, Chenopodium album and Stellaria media. All of these species are capable of producing large amounts of seeds. Menalled and Schonbeck (2013) state, if the management of weed control is changed, the content of seeds in the soil supply will change too. It is very clear from the results (Fig. 3) that variant of maintenance had a highly statistically significant impact on the number of seeds in the soil.

\section{Untreated control}

The highest number of seeds, of course, was recorded on this variant. The occurrence of seeds of the Amaranthus genus was the most common. The content of the Chenopodium album was also significant. According to Schroeder et al. (1993), it belongs to the most important types of weeds in Europe. Mikulka and Chodová (1996) report that one plant produces more than 100,000 seeds. Authors Pikula, Obdržálková and Zapletal (1997) report the production of 20,000 to 200,000 seeds. Slawinski and Golabek (2010) report that
Chenopodium album especially is the most widespread weed in the soil seedbank and it often makes up more than $50 \%$ of stock. This result was also recorded in our experiment. Seeds retain long germination in the soil.

The seeds of the Stellaria media were appeared in the soil seedbank. According to Schroeder et al. (1993), Stellaria media also belongs to the most important types of weeds in Europe. Lososová and Simonová (2008) report that Stellaria media is one of the most frequently occurring species in the Czech Republic. They further state that this species is capable of flowering all year round. On this variant were made minimal interventions during the vegetation. Probably a thousand seeds grow on one plant per year. In addition, Kohout (1997) report that the seeds will last for several years in the soil.

\section{Chemical method of weed management}

There is also a visible decrease in the number of seeds in the soil in the chemically controlled variant, but it is not as remarkable as in the mechanically controlled variant. The difference between the years 2013 and 2014 is not so visible as at variant of mechanical variant. The genus of Amaranthus had the largest number of seeds in the soil. It is probably 
due to the time of the application of the herbicide Basta 15. It was applied in May and June 2013. Another chemical treatment was not carried out. Since plants of the genus Amaranthus are late spring species, the plants that grew later probably remained unaffected, and they released a large number of seeds into the soil. Stevens (1957) states that one Amaranthus retroflexus plant is capable of producing up to 500,000 seeds under optimum conditions. Experiments to maintain seed germination differ in their results. Maintenance of germination is very variable and probably depends on local climatic and ecological conditions. Darlington and Steinbauer (1961) state that the maintenance of germination capacity is up to 40 years. Authors Tool and Brown (1946) state 10 years, Dvořák and Smutný (2003) state 3-10 years, Kohout (1997) 1 to 10 years.

\section{Mechanical method of weed management}

The number of seeds in the soil in the mechanically controlled variant, is significantly lower than in the other variants. The lowest number of seeds of Amaranthus sp. was found in the mechanically controlled variant. This genus made up the largest number of seed in the soil stock, but is really well regulated by mechanical method. As Ivashchenko (2014) presents, damage of plants at a phase of two leaves led to dying off of $98 \%$ of total number. The ability of plants to overcome induced stresses is raised with increase of their growth phases. At a phase of 6 leaves died off $70 \%$ from their total.

Seeds of Portulaca oleracea made up 9\% of the soil seedbank. Purslane can produce 100,000 to 242,000 seeds per year. It keeps very good germination capacity (up to $90 \%$ ) even after 2 years. The results of some studies prove germination even after 40 years. Koch and Kennedy (1982) predicates, thanks to C4 metabolism, it tolerates very high temperatures without a sufficient amount of water. The results of the experiment by Lara et al. (2003) suggest that in plants stressed by drought, after approximately 20 days, there occurs a metabolic change that is very similar to CAM (Crassulean Acid Metabolism) plants. This kind does not pose a greater danger to the grapevine. However, due to the metabolism of this species, there is a strong premise that its importance will rise. The most seeds were found in the soil sample from the mechanically controlled variant, the least in the control variant. It was probably caused by a low current weed infestation by this species.

It is not possible to clearly identify, which weed management method is the most effective. It is probable that a combination of chemical and mechanical weed management would lead to a further reduction in the number of seeds in the soil. Several authors, for example, Rotim (2016), Wolf (2008), and others incline to this conclusion.

\section{CONCLUSION}

Weed seedbank in the soil was evaluated in the places below the grapevine. in years 2013 and 2014. The analysis of soil samples confirmed the presence of seeds that belonged to 24 plant species. In all three variants, irrespective of the weed control method, the largest number of seeds was from the same species (Amaranthus sp., Chenopodium album, Stellaria media and Portulaca oleracea). The largest number of seeds was found in the soil of the untreated variant. A lower number of seeds was found in the chemically controlled variant. The lowest number of seeds was found in the soil of mechanically controlled places. The analysis of variance confirmed that in the mechanically controlled variant, a lower number of seeds compared to the untreated variant is statistically high significant (at the level of significance $\alpha=0.01$ ). The statistical difference in the number of seeds in the chemically controlled variant and the untreated variant was not confirmed. There was no statistical difference in the number of seeds either between the chemically or mechanically controlled variants.

Seeds of the species Chenopodium album and Stellaria media occurred the least in the chemically controlled variant. Although the lowest number of seeds was found in the mechanically controlled variant, it cannot be said with certainty that this method of weed control is the most effective in reducing the number of weed seeds in the soil. Two-year observation is too short to draw deeper conclusions because changes in weed seedbank are quite dynamic.

In spite of this short timeframe, it can be deduced from the evaluation of weed seedbank that a greater attention should be paid to control of Amaranthus sp. and Chenopodium album in the future. These robust species not only take a large number of nutrients from the vineyard, but also a great deal of valuable moisture.

\section{REFERENCES}

CABALLERO, I., OLANO, J. M., LOIDI, J. and ESCUDERO, A. 2008. A model for small-scale seed bank and standing vegetation connection along time. Oikos, 117: 1788-1795.

CABALLERO, I., OLANO, J. M., LUZURIAGA, A. L. and ESCUDERO, A. 2005. Spatial coherence between seasonal seed banks in a semi-arid gypsum changes but structure does not. Seed Science Research, 15: 153-160.

CAETANO, R. S. X., CHRISTOFFOLETI, P. J. and VICTORIA-FILHO, R. 2001. „Banco“ de sementes de plantas dahinhas em pomar de laranjeira „Pera“. Scientia Agricola, 58(3): 509-517. 
DARLINGTON, H. T. and STEINBAUER, G. P. 1961. The eighty-year period for Dr. Beal's seed viability experiment. Amer. J. Bot., 48: 321-325.

DVOŘÁK, J. and KREJČÍŘ, J. 1973. Contribution to the identification of the relationship between actual weed infestation and the quantity of selected annual weeds seeds and fruits in the topsoil [in Czech: Příspěvek ke zjištení vztahu akutního zaplevelení k množství semen a plodů některých jednoletých plevelů v ornici]. Rostlinná výroba, 46(19): 975-982.

DVOǨÁK, J. and SMUTNÝ, V. 2003. Herbology: Integrated protection against field weeds [in Czech: Herbologie: Integrovaná ochrana proti polním plevelim ]. Brno: MZLU.

DVOŘÁK, J. and SMUTNÝ, V. 2011. The effects of crop rotation and herbicides on weed seed bank in the soil [In Czech: Vlivy osevních postupů a herbicidů na zaplevelení ornice semeny plevelů]. In: Folia univ. agric. et silvic. Mendel. Brun., 4, No. 4.

IVASHCHENKO, O. 2014. Influence of thermal and mechanical stresses on Amaranthus retroflexus L. plants. Herbologia, 14(2): 27-34.

KOHOUT, V. 1997. Weeds on fields and gardens [in Czech: Plevele poli a zahrad]. $1^{\text {st }}$ Edition. Praha: Agrospoj.

KOCH, K. E. and KENNEDY, R. A. 1982. Crassulacean acid metabolism in the succulent C4 dicot, Portulaca oleracea L. under natural environmental conditions. Plant Physiology, 69(4): 757-76l.

LARA, M., DISANTE, K., PODESTÁ, F., ANDREO, C. and DRINCOVICH, M. 2003. Induction of a Crassulacean acid like metabolism in the C4 succulent plant, Portulaca oleracea L.: physiological and morphological changes are accompanied by specific modifications in phosphoenolpyruvate carboxylase. Photosynthesis Research, 77(2/3): 241-254.

LOSOSOVÁ, Z. and SIMONOVÁ, D. 2008. Changes during the 20th century in species composition of synanthropic vegetation in Moravia (Czech Republic). Preslia, 80: 291-05.

MARHOLD, K. and HINDÁK, F. 1998. Checklist of Non-Vascular and Vascular Plants of Slovakia [in Slovakia: Zoznam nižšich a vyššich rastlín Slovenska]. Bratislava: Veda.

MENALLED, F. and SCHONBECK, M. 2013: Manage the Weed Seed Bank-Minimize "Deposits" and Maximize "Withdrawals". eXtension. [Online]. Available at: http://www.extension.org/pages/18527/ manage-the-weed-seed-bankminimize-deposits-and-maximize-withdrawals\#.Um-TxBBtao9. [Accessed: 2018, September 4].

MIKULKA, J. and CHODOVÁ, D. 1996. Control of herbicide resistant weeds [in Czech: Hubení plevelů odolných vůči herbicidiom]. Praha: Institut výchovy a vzdělávání MZe.

MIRITI, M. N., RODRÍGUEZ-BURITICÁ, S., WRIGHT, S. J. and HOWE, H. F. 2007. Episodic death across species of desert shrubs. Ecology, 88: 32-36.

OLANO, J. M., CABALLERO, I. and ESCUDERO, A. 2012. Soil seed bank recovery occurs more rapidly than expected in semi-arid Mediterranean gypsum vegetation. Ann Bot., 109(1): 299-307.

PIKULA, J., OBDRŽÁLKOVÁ, D. and ZAPLETAL, M. 1997. Atlas of selected weed species in the Czech Republic [in Czech: Atlas vybraných druhi plevelu v ČR]. Praha: Ústav zemědělských a potravinářských informací.

ROTIM, N. 2016: Weed control in vineyards. [in Croatian: Suzbijanje korova u vinogradima]. Glasnik zaštite bilja, 39(3): 80-85.

SCHNEIDER, C. A., RASBAND, W. S. and ELICEIRI, K. W. 2012. NIH Image to ImageJ: 25 years of image analysis, Nature methods, 9(7): 671-675.

SCHROEDER, D., MUELLER-SCHAERER, H. and STINSON, C. S. A. 1993. A European weed survey in 10 major crop systems to identify targets for biological control. Weed Res., 33: 449-458.

SLAWINSKI, J. and GOLABEK, E. 2010. Influence of farming systems on the number and biodiversity of weed seeds in a soil bank. In: WACLAWEK, M. (Ed.). Proceedings of ECOpole, 4(1): 73-77.

SMUTNÝ, V. and KŘEN, J. 2002. Improvement of an elutriation method for estimation of weed seedbank in the soil. Rostlinná výroba, 48(6): 271-278.

STEVENS, O. 1957. Weights of seeds and numbers per plant. Weeds, 5: 46-55.

TOOLE, E. H. and BROWN, E. 1946. Final results of the Duvel buried seed experiment. J. Agric. Res., 72: 201-210.

VÚPOP Bratislava. 2017. Soil portal. [in Slovak: Pôdny portál]. [Online]. Available at: http://www.podnemapy. sk/portal/verejnost/obj_hmotnost/obj_hmotnost.aspx [Accessed: 2018, September 4].

WOLF, T. K. (Ed.). 2008. Wine Grape Production Guide for Eastern North America. $1^{\text {st }}$ Edition. Ithaca, NY: Natural Resource, Agriculture, and Engineering Service.

Lenka Porčová: lenka.porcova@mendelu.cz

Vladimír Smutný: smutny@mendelu.cz 